\title{
Transgenic Mouse Facility
}

National Cancer Institute

\section{Source}

National Cancer Institute. Transgenic Mouse Facility. NCI Thesaurus. Code C16023.

A shared facility for creation and propag ation of transgenic mice. 